\title{
Chemical, Functional and Nutritional Characteristics of Weaning Food Formulations
}

\author{
RASHMI KUMKUM, CHIKKE GOWDA, ANJUM KHANAM and BHAGYA SWAMYLINGAPPA*
}

\author{
Department of Protein Chemistry and Technology, Central Food Technological Research Institute, \\ Council of Scientific and Industrial Research, Mysore 570020, India
}

Two ready to eat weaning food formulations have been developed based on oilseed. Wheat, green gram Dhal, sugar and cereal malt have been incorporated to provide 15-17\% protein and 360-380 Kcal of energy and fortified with vitamins and minerals to meet the recommended daily allowance. The physico-chemicals, functional and nutritional characteristics of the formulations were evaluated. The chemical score indicated that sulphur containing amino acids were first limiting amino acid in both the formulations. However, the calculated nutritional indices: essential amino acid index, nutritional index biological value and C-PER were higher for formula-II. The rat bioassay showed higher PER (2.07) for formula-II. Sensory studies confirmed that the products were acceptable with a shelf life of one year under normal storage conditions. The product could be served in the form of porridge with water/milk or in the form of small Laddu.

Keywords: Functional, Nutritional characteristics, weaning food, Pre-school children

\section{Introduction}

Developing nutrient dense, fully cooked, ready to eat inexpensive supplementary foods from the locally grown food ingredients has been strongly recommended as a viable and sustainable approach to address the problem of under nutrition in developing countries (WHO/UNICEF, 1998; WHO, 2002; Dewey and Brown, 2003). Acute infection is a key point of vulnerability in malnutritioned children, leading to increased susceptibility to further infection and in some cases death. Although significant progress has been made over the past few decades in reducing the prevalence of malnutrition, recent data show that the prevalence of underweight and stunting has more than doubled in subsaharan Africa and South Asia continues to be home to nearly half of the world's under nourished children (UNICEF, 2006; Black et al., 2008). The childhood diet must be adequate to support normal growth and development and appropriate amounts of minerals are required since the deficient intake of certain minerals can produce diseases and lead to abnormal development (Favier, 1993). Adequate nutrition during the first two years after birth is critical to ensure optimal physical and mental development of infants and young children. Mother's are increasingly unable to provide much needed food for their young children and often can not breast feed their infants as they are themselves suffering from malnutrition, so for those young children aged one to three years, formulations were to be specially designed as a weaning food added to a normal diet to provide adequate intake of energy and nutrients to meet the individual's requirement (Rashmi and Swamylingappa 2009).

Strategies to improve the availability and accessibility to low cost fortified complementary foods can play an important role in behavioral changes necessary to improve the

\footnotetext{
*Corresponding author, E-mail: bhagguru@yahoo.com
}

nutritional status of infants and young children (Rivera et al., 2001). Enrichment of nutrients (vitamins and minerals) was established as a measure either to correct or prevent nutritional deficiencies in populations or to restore nutrients lost during food processing. Calcium is an important element, which is associated with increased bone mass during adolescence, facture and bone fragility when supplemented in children (Hallfrisch et al., 2000). Iron deficiency is a serious health problem affecting a large portion of the world's population causes anemia and related cognitive and intellectual impairment in children. Therefore the objective of the study was to develop two specially designed weaning food formulations based on locally available cereal, pulse, oilseed flour and soy protein concentrate and to evaluate the nutritional and functional characteristics of the formulations.

\section{Materials and Methods}

Wheat, green gram dhal, sugar and malt were purchased from the local market, Karnataka, India. Vitamin premix from Nicholas and Primal India, Mumbai, Ferrous sulphate and Calcium carbonate from S. D. Fine Chemicals. Pepsin, pancreatin, Bile mixture was obtained from Sigma Chemicals Co. All other chemicals were used of analytical grade.

Preparation of Soy protein concentrate (SPC): The defatted soy grits were obtained from M/S Shakthi, Coimbatore, Tamil Nadu. The grits were processed according to the method of Obulesu and Swamylingappa (2006). The grits were powdered to pass through a 60 -mesh sieve for further use.

Preparation of weaning food: Wheat, Soy protein concentrate, Groundnut flour and green gram dhal were roasted separately and optimally to golden brown and powdered and passed through a 60-mesh sieve. All the powdered ingredients and malt were weighed in to a container and mixed thoroughly in a Hobart mixer for $5 \mathrm{~min}$ and stored in an airtight container for analysis (Figure1). 


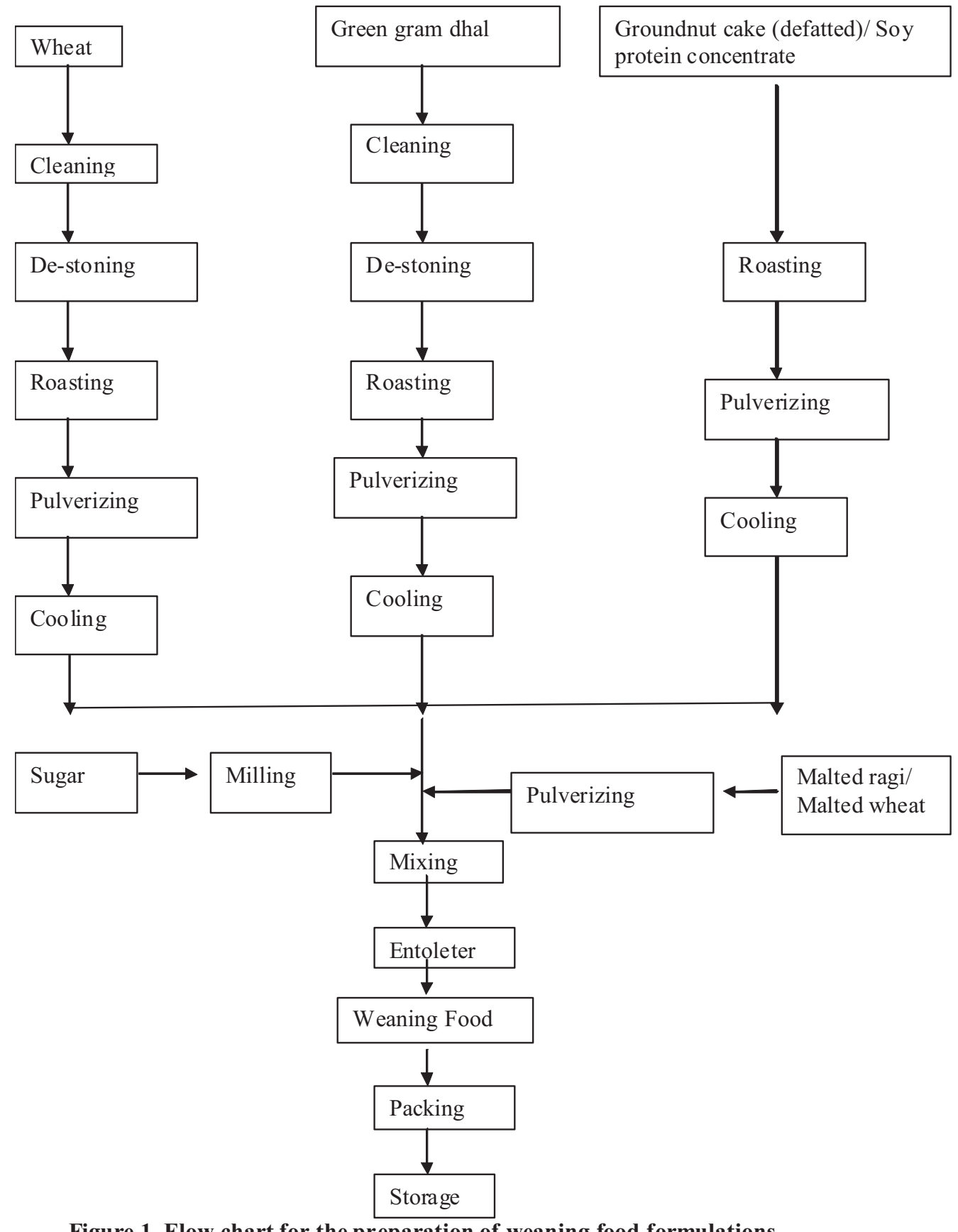

Figure 1. Flow chart for the preparation of weaning food formulations

Chemical composition: Moisture, Protein ( $\mathrm{N}$ x 6.25), fat, ash and crude fiber according to the method of AOAC (2000). Total iron, calcium and zinc were determined by atomic Absorption spectrometry (Shimadzu AAF-6701, Tokyo), using standard conditions as recommended by the manufacturer. The procedure of Thompson and Erdman (1982) was used for phytic acid estimation by converting ferric phytate and the phosphorus content analyzed by method of Taussky and Shorr
(1953). Phytic acid content was derived from phytate phosphorus was by multiplying by a factor of 3.55 .

Functional properties: The weaning food formulations were subjected to determination of various functional properties such as water holding capacity (Prasanappa et al., 1972), Bulk density (Wang and Kinsella, 1976). Apparent viscosity was measured using Brook field viscometer using spindle No.10 at $100 \mathrm{rpm}$. The colour measurement was determined using 
the Minolta CM 3500D (Japan) instrument using visible wavelength. Colors of samples were measured by $\mathrm{C}$ illuminating 2D view angle. The values of $L$ (Lightness), $a$ (redness and greenness), $b$ (blueness and yellowness) was measured using the Hunter color system.

Evaluation of nutrition quality: The nutrition quality of the formulations was assessed by various methods viz. In vitro Protein digestibility was determined by the method of Akeson and Stahman (1964) using pepsin and pancreatin enzymes, the difference protein relative to the total protein was expressed as percent digestibility. Amino acid analysis was analyzed using a method of Bidling Meyer et al., 1984. Tryptophan was estimated by the acid ninhydrin method (Pinter and Molnar, 1990). Chemical score was calculated according to the method of FAO 1968. Essential amino acid index was calculated according to the method of Oser (1951). Biological value was calculated using the formula of Oser (1959). Nutritional index (NI) was calculated according to Crisan and Sands (1978). Computed protein efficiency ratio (C-PER) was calculated according to the method of Satterlee et al., (1979). Protein Digestibility corrected amino acid score (PDCAAS) was calculated according to the method of Sarwar and McDonough (1990) for 2-5 years, 10-12 years old children and adults. Protein efficiency ratio (PER by rat bio-assay method) was determined in the weaning food according to the BIS standard method (IS: 7481-1974). Casein was used as standard reference protein. Available lysine was determined by FDNB reactive lysine method of Carpenter et al., (1960) as modified by Booth et al., (1971).

Sensory analysis: A trained panel was employed for carrying out sensory evaluation following the method of Quantitative Descriptive Analysis (QDA) (Stone and Sidel 1998). Descriptors and panels were developed during initial session by the panelists. Each member was asked to describe the samples with as many spontaneous descriptive terms as they found applicable. The common descriptors such as colour, flavour and taste chosen by at least one third of the panel were compiled along with some impact descriptors for preparing scorecard. The panel consisted of 12 judges who regularly participated in sensory analysis studies and had experience in profiling of food products. The sample was served in Petri dishes coded with three digit numbers. Evaluation was carried out in booth rooms built in accordance with the ASTM standards (ASTM, 1996).

QDA method of intensity scaling was used .The scorecard consisted of $15 \mathrm{~cm}$ scale where in $1.25 \mathrm{~cm}$ was anchored as "low" and $13.75 \mathrm{~cm}$ as "high". The panel was asked to mark the intensity of the attribute by drawing a vertical line on the scale and writing the code, but the overall quality (OQ) was evaluated on an intensity scale which was anchored at very poor, fair and very good to see the liking or preference of supplementary food by panel members. The mean score of individual attributes were calculated and profilogram was drawn.

Storage Studies: About 250g samples were packed in 300 gauge LDPE pouches and exposed to $90 \% \mathrm{RH}$ and $38 \pm 1{ }^{\circ} \mathrm{C}$. The product samples were withdrawn periodically every month and subjected for sensory analysis and moisture estimations.

Statistical analysis: All the values expressed as mean \pm standard deviation. t-test was performed using one way ANOVA to obtain the significance between the two food formulations.

\section{Results and Discussion}

The ingredients composition of weaning food formulations based on cereal, pulse, oil seed flour, protein concentrate, sugar, vitamins and minerals is presented in Table1.

Table 1. Composition of ingredients used in weaning food formulations

\begin{tabular}{lcc}
\hline Ingredients & $\begin{array}{c}\text { Weaning } \\
\text { food-I }\end{array}$ & $\begin{array}{c}\text { Weaning } \\
\text { food-II }\end{array}$ \\
\hline $\begin{array}{l}\text { Wheat Flour } \\
\text { (Roasted Powdered) }\end{array}$ & 45 & 45 \\
$\begin{array}{l}\text { Soy Protein Concentrate } \\
\text { (Roasted Powdered) }\end{array}$ & - & 10 \\
$\begin{array}{l}\text { Ground nut Flour } \\
\text { (roasted) }\end{array}$ & 10 & - \\
$\begin{array}{l}\text { Green gram dhal } \\
\text { (roasted, Powdered) }\end{array}$ & 10 & 10 \\
$\begin{array}{l}\text { Wheat malt } \\
\text { Sugar powder }\end{array}$ & 8 & 8 \\
$\begin{array}{l}\text { Vitamin premix } \\
\text { Minerals }\end{array}$ & 27 & 27 \\
Calcium Carbonate & 0.09 & 0.09 \\
Ferrous Sulphate & 0.9 & 0.9 \\
\hline
\end{tabular}

The chemical composition of the weaning food formulations is given in Table 2. The formulations provide $15-16 \mathrm{~g}$ of protein and 375-380 kcal per 100g product. Baskaran et al., (1999) have reported that the protein content of $10.5-12.5 \%$ and 340 to $398 \mathrm{kcal}$ energy for the supplementary food prepared from popped cereals. The total ash content of SPC based formulaII was higher $3.0 \mathrm{~g} / 100 \mathrm{~g}$ than the groundnut protein based formula-I $(2.5 \mathrm{~g} / 100 \mathrm{~g})$. However, both the formulations were similar and did not show any significant difference in other constituents. In addition, it also provides $100 \%$ of the 
Kumkum ot al., : J. Food Sci. \& Technol. Nepal, 6 (36-42), 2010

Table 2. Chemical composition of weaning food formulations

\begin{tabular}{lll}
\hline Constituents (\%) & Weaning food-I & Weaning food-II \\
\hline Moisture & $2.5 \pm 0.1 \mathrm{e}$ & $2.6 \pm 0.2 \mathrm{c}$ \\
Fat & $1.2 \pm 0.02 \mathrm{e}$ & $0.95 \pm 0.01 \mathrm{a}$ \\
Protein (NX6.25) & $15.11 \pm 0.06 \mathrm{e}$ & $15.94 \pm 0.13 \mathrm{~b}$ \\
Total Ash & $2.5 \pm 0.01 \mathrm{e}$ & $3.0 \pm 0.01 \mathrm{a}$ \\
Acid Insoluble Ash & $0.057 \pm 0.001 \mathrm{e}$ & $0.057 \pm 0.001 \mathrm{~d}$ \\
Crude fibre & $1.55 \pm 0.08 \mathrm{e}$ & $1.5 \pm 0.005 \mathrm{~d}$ \\
Carbohydrate (by diff.) & $77.14 \pm 0.3 \mathrm{e}$ & $76.01 \pm 0.16$ \\
Energy (kcal) & 380 & 376 \\
Thiamine (mg)* & 1.305 & 1.233 \\
Riboflavin $(\mathrm{mg})^{*}$ & 1.023 & 1.045 \\
Niacin (mg)* & 11.194 & 9.76 \\
Vitamin B12 ( $\mu \mathrm{g})^{*}$ & 0.45 & 0.45 \\
Folic acid $(\mu \mathrm{g})^{*}$ & 483 & 512.97 \\
Iron (mg) & $12.75 \pm 0.75 \mathrm{e}$ & $13.93 \pm 0.43 \mathrm{~b}$ \\
Calcium (mg) & $393.75 \pm 6.25 \mathrm{e}$ & $431.25 \pm 6.25 \mathrm{c}$ \\
Zinc (mg) & $2.65 \pm 0.01 \mathrm{e}$ & $2.28 \pm 0.03$ \\
Phytic acid & $0.526 \pm 0.005 \mathrm{e}$ & $0.532 \pm 0.005 \mathrm{~d}$ \\
\hline
\end{tabular}

* Mean $\pm S D$; values having different superscripts in a row are significantly different at $(p<0.05)$

Recommended Daily Allowances (RDA) of vitamins, 393$431 \mathrm{mg}$ of calcium, $12-14 \mathrm{mg}$ of iron, $2.2-2.6 \mathrm{mg}$ of zinc in $100 \mathrm{~g}$ of weaning food formulations. Zinc plays role in normal growth and development of immunity also has role in gene expression, cell regulation, cell differentiation (Hambidge, 2000). Iron is an essential element for the formation of hemoglobin of red cells of blood and plays an important role in the transport of oxygen. The amount of iron to be absorbed from the daily diet is $1-3 \mathrm{mg}$. Since, there is limited capacity to absorb dietary iron; diet should contain 10-25-folds iron required daily. The phytic acid content of both the formulations did not differ significantly.

The amino acid composition of weaning food formulations, along with that of reference soy protein (FAO/WHO, 1985) is presented in Table 3 . The amino acid profiles of both the samples contain fairly adequate quantities required for growth and development of children of the age group 2-5 and 10-12 years. However, sulphur containing amino acids are the limiting.

The nutritional characteristics are given in Table 4. The In vitro protein digestibility of weaning food formula-II was relatively higher $(91 \%)$ than formula-I. This could be attributed to removal of anti-nutritional factors during processing of SPC. The computed nutritional indices EAAI, BV and nutritional index for the formula-II was slightly higher than that of formula-I, clearly indicating the excellent quality of
Table 3. Essential amino acid composition of the weaning food formulations

\begin{tabular}{lll}
\hline Constituents (\%) & Weaning food-I & \multicolumn{1}{c}{ Weaning food-II } \\
\hline Moisture & $2.5 \pm 0.1 \mathrm{e}$ & $2.6 \pm 0.2 \mathrm{c}$ \\
Fat & $1.2 \pm 0.02 \mathrm{e}$ & $0.95 \pm 0.01 \mathrm{a}$ \\
Protein (NX6.25) & $15.11 \pm 0.06 \mathrm{e}$ & $15.94 \pm 0.13 \mathrm{~b}$ \\
Total Ash & $2.5 \pm 0.01 \mathrm{e}$ & $3.0 \pm 0.01 \mathrm{a}$ \\
Acid Insoluble Ash & $0.057 \pm 0.001 \mathrm{e}$ & $0.057 \pm 0.001 \mathrm{~d}$ \\
Crude fibre & $1.55 \pm 0.08 \mathrm{e}$ & $1.5 \pm 0.005 \mathrm{~d}$ \\
Carbohydrate (by diff.) & $77.14 \pm 0.3 \mathrm{e}$ & $76.01 \pm 0.16$ \\
Energy (kcal) & 3801 & 376 \\
Thiamine (mg) & 1.305 & 1.233 \\
Riboflavin (mg)* & 1.023 & 1.045 \\
Niacin (mg) & 11.194 & 9.76 \\
Vitamin B12 ( $\mu \mathrm{g})^{*}$ & 0.45 & 0.45 \\
Folic acid $(\mu \mathrm{g})^{*}$ & 483 & 512.97 \\
Iron (mg) & $12.75 \pm 0.75 \mathrm{e}$ & $13.93 \pm 0.43 \mathrm{~b}$ \\
Calcium (mg) & $393.75 \pm 6.25 \mathrm{e}$ & $431.25 \pm 6.25 \mathrm{c}$ \\
Zinc (mg) & $2.65 \pm 0.01 \mathrm{e}$ & $2.28 \pm 0.03$ \\
Phytic acid & $0.526 \pm 0.005 \mathrm{e}$ & $0.532 \pm 0.005 \mathrm{~d}$ \\
\hline
\end{tabular}

-Determined by acid ninhydrin method, Mean \pm SD; values having different superscri in a row are significantly different at $(p<0.05)$

soy protein than the groundnut proteins based formula. Both the formulations did not show any significant difference in the available lysine content. The calcium and Iron content of the formula-II was higher and it could be attributed to soy 
Table 4. Nutritional characteristics of weaning food formulations

\begin{tabular}{lll}
\hline Parameters & Weaning food-I & Weaning food-II \\
\hline In-vitro Protein digestibility (\%) & $90.2 \pm 1.1 \mathrm{e}$ & $90.94 \pm 0.37 \mathrm{~d}$ \\
EAA Index (\%) & 63.74 & 71.76 \\
Predicted biological value (\%) & 57.78 & 66.52 \\
Nutritional index & 10.2 & 11.84 \\
C-PER & 1.8 & 1.9 \\
PER (Rat bio assay) & $2.02 \pm 0.07 \mathrm{e}$ & $2.07 \pm 0.10$ \\
Chemical score & 73.5 & 80.5 \\
Limiting amino acid & S-Amino Acids & S-Amino Acids \\
& 0.5 & 0.59 \\
PDCAAS 10-5 years $\quad$ Adults years & 0.6 & 0.89 \\
& 1.0 & 1.0 \\
Available Lysine (g/100gprotein) & $2.9 \pm 0.01 \mathrm{e}$ & $2.6 \pm 0.08 \mathrm{~d}$ \\
Bio-available Iron (mg/100g) & $2.8 \pm 0.3 \mathrm{e}$ & $3.37 \pm 0.03 \mathrm{~d}$ \\
\hline
\end{tabular}

Mean $\pm S \bar{D}$; values having different superscripts in a row are significantly different at $(p<0.05)$

protein concentrate. Luis (1994) has reported that iron salt ferrous sulphate and calcium carbonate used for fortifying showed highest bioavailability.

The functional properties of weaning food formulations are presented in Table 5. The bulk density of both the formulations was $0.76 \mathrm{~g} / \mathrm{ml}$, indicating that more food can be consumed in a given volume of weaning food. These results correlates well with the suggestions of White Head (1973) that, supplementary food meet for children should not provide high proteins and energy but also would be low in bulk since stomach capacities are smaller (Ljungquist et al., 1981). Weaning foods given in the form of gruels are usually prepared by dispersing in cold or warm water or milk. It was therefore interesting to study the water holding capacity (WHC) and viscosity at room temperature $25^{\circ} \mathrm{C}$ and at temperature 60 $\pm 1^{\circ} \mathrm{C}$. The amylase rich wheat malt was used to easy the digestion, avoids producing gas after eating, reduces dietary bulk or viscosity. The viscosity of the weaning food gruels decreased with increase in shear rate and temperature (Mamudu et al., 2006). The WHC of formula-I was $1.29 \mathrm{~g} / \mathrm{g}$ at $60 \pm 1^{\circ} \mathrm{C}$ may be due to gelatinization of the product.

The colour measurement data is given in Table 5 . The $L$ value (lightness) was 83.65 and 82.80 for formula-I and II respectively. Formula-I was slightly creamy in colour than the formula-I. The $b$ value (redness) was 11.37 and 11.81 for formula-I and II respectively. This was due to the effect of soy processing. However, $\triangle \mathrm{E}$ value (total colour) was 12.87 and 13.70 for formula-I and II indicating that the redness of both formulations were negative as there was no ingredient, which contributed for redness.

Sensory evaluation result for formula-I and formula-II is shown in Figure 2. Formula-II was significantly superior in texture and high acceptability range of colour and taste. As seen from the graph, the pasty texture was slightly more in formula-I. In formula-II more cereal like aroma was noticed. The sweetness did not differ significantly $(p>0.05)$ between samples. However, the overall quality of formulations was acceptable.
Table 5. Functional characteristic of weaning food formulations

\begin{tabular}{lcl}
\hline Properties & Weaning food-I & Weaning food-II \\
\hline Bulk Density (g/ml) & $0.76 \pm 0.01 \mathrm{e}$ & $0.76 \pm 0.02 \mathrm{~b}$ \\
Water Holding Capacity $(\mathrm{g} / \mathrm{g})$ & \\
at $25 \pm 1^{\circ} \mathrm{c}$ & $1.29 \pm 0.012 \mathrm{e}$ & $1.25 \pm 0.027 \mathrm{~d}$ \\
at $60 \pm 1^{\circ} \mathrm{c}$ & $1.92 \pm 0.025 \mathrm{e}$ & $2.00 \pm 0.005 \mathrm{~d}$ \\
Viscosity (centipoises) & & \\
at $25 \pm 1^{\circ} \mathrm{c}$ & $54.0 \pm 2.0 \mathrm{e}$ & $58.0 \pm 0.01 \mathrm{~b}$ \\
at $60 \pm 1^{\circ} \mathrm{c}$ & $104.0 \pm 2.0 \mathrm{e}$ & $84.0 \pm 4.0 \mathrm{a}$ \\
Pat spread & & \\
at $25 \pm 1^{\circ} \mathrm{c}$ & $4.15 \pm 0.15 \mathrm{e}$ & $4.4 \pm 0.1 \mathrm{c}$ \\
at $60 \pm 1^{\circ} \mathrm{c}$ & $3.1 \pm 0.1 \mathrm{e}$ & $3.95 \pm 0.05 \mathrm{a}$ \\
Water required for the unit spread (g/g) of product \\
at $25 \pm 1^{\circ} \mathrm{C}$ & 2 & 2 \\
at $60 \pm 1^{\circ} \mathrm{C}$ & 2 & 2 \\
Colour measurement & \multicolumn{3}{c}{} \\
$L$ value (Lightness) & $83.65 \pm 0.01 \mathrm{e}$ & $82.80 \pm 0.01 \mathrm{a}$ \\
a value(Greenness) & $-0.26 \pm 0.001 \mathrm{e}$ & $-0.34 \pm 0.031 \mathrm{a}$ \\
$b$ value (Redness) & $11.37 \pm 0.01 \mathrm{e}$ & $11.81 \pm 0.01 \mathrm{a}$ \\
$\Delta$ E value (Total colour) & $12.87 \pm 0.005 \mathrm{e}$ & $13.70 \pm 0.005 \mathrm{a}$ \\
\hline
\end{tabular}

Mean \pm SD; values having different superscripts in a row are significantly different at $(\mathrm{p}<0.05)$

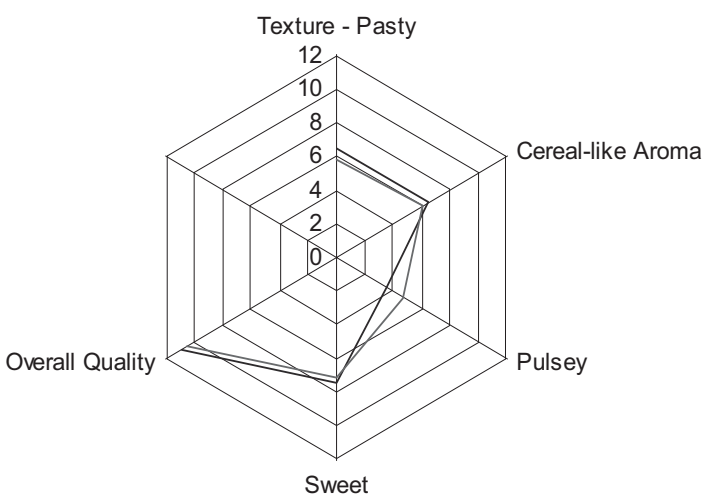

Formulation-I __ Formulation-II

Figure 2. Sensory evaluation result for weaning foods 
Storage studies indicated that the product has about 4 months shelf-life under accelerated storage condition of $90 \% \mathrm{RH}$ and $38 \pm 1^{\circ} \mathrm{C}$. This clearly implies a shelf life of about one year under normal storage condition of $65 \% \mathrm{RH}$ and $27 \pm 1^{\circ} \mathrm{C}$ in the same LDPE package.

\section{Conclusion}

In conclusion, the weaning food formulations based on groundnut flour and soy protein concentrate as sources of protein were acceptable. Between the two formulations, soy protein based formulation was nutritionally better as compared to groundnut protein based formulation. However, depending on the availability of raw materials both the weaning food formulations can be formulated to meet the nutritional needs of the children.

\section{Acknowledgements}

The authors are grateful to Dr. V. Prakash, Director, Central Food Technological Research Institute, Mysore, India, for his keen interest during the course of the investigation. Thanks to Dr. A.G. Appu Rao for his valuable suggestions. Finally, the authors are grateful to Dr. (Mrs.) Lalitha R. Gowda for her help with the analysis of amino acids and Dr. (Mrs) Maya Prakash, Head, Department of Sensory Science for her help in sensory studies.

\section{References}

Akeson W. R. and Stahman M. A. (1964). A pepsin pancreatin digest index of protein quality evaluation. J. of Nutr., 83: 257-261.

AOAC (2000). Official Methods of Analysis, (17 thedn) Association of Official Analytical Chemists, DC.

ASTM (1996). Sensory testing methods. In: ASTM manual 26, 2nd edn, (E. chamber IV and M.B. Wolf, Eds) ASDTM, West Conshohocken, A, pp 54-72.

Baskaran V., Mahadvamma, Malleshi N. G., Shankara R., Lokesh B. R. (1999) Acceptability of supplementary foods based on popped cereals and legumes suitable for rural mothers and children. Plant Food Hum Nutr., 53:237-247.

Bidlingmeyer B. A., Cohen S. A. and Tarvin T. L. (1984). Rapid analysis of amino acids using pre-column derivatization. J. of Chrom., 336: 93-104.

Black R. E. Allen L. H. and Bhutta Z. A. (2008). Maternal and Child under- nutrition: Global and regional exposures and health consequences. Lancet, 371: 243-60.

Booth V. H. (1971). Problems in the determination of FDNBavailable lysine. J. of Sci. of Food and Agri., 22:658-664.

Carpenter K. J. (1960). The estimation of available lysine in animal protein foods. J. of Biochem., 77: 604-610.

Crisan E. V. and Sands A. (1978). Biology and cultivation of edible Mushrooms, Academic press. Newyork, pp 137 142.
Dewey K. G. and Brown K. H. (2003). Update on technical issues concerning complementary feeding of young children in developing countries and implications for intervention program. Food and Nutri. Bulletin. 24: 528.

FAO (1968). Amino Acid content of Food and Biological Data on protein, UN Food and Agriculture organization, Rome.

FAO/WHO/UNO. (1985). Energy and protein requirements, WHO Technical Report Series No. 724, Geneva, Switzerland.

Favier A. E. (1993). Nutritional and Clinical factors affecting the bioavailability of trace elements in humans. Proceedings of the international conference bioavailability '93 Nutritional, Chemical and Food processing implications of nutrient availability Karlsruhe, pp 202-212.

Hallfrisch J. Veillon C. Patterson K. Hill A. D. Benn I. Holiday B., Burns R., Zhonnie S., Price F. and Sorenson A. (2000). Bone related mineral content of water samples collected on the Navojo reservation. Toxicology. 149: 143-148.

Hambidge M. (2000). Human Zinc deficiency. J. of Nutri., 130: 1344S-1349S.

ISI (1996). Indian Standard Method for determination of Protein Efficiency ratio (7481:1974), Indian Standards Institution, New Delhi.

Ljungquist B. G., Mellandr O. and Svanberg U. (1981). Dietary bulk as a limiting factor for nutritive intake in pre school children. J. Troprical Pediatrics, 27:68-73.

Luis A. M. (1994). Fortification of foods; Historical development and current practices. Food and nutria. Bulletin, 15.

Mamudu H. B., Israel A. J. and Iro N. (2006). Rheological behavior of weaning food formulations as affected by addition of malt. Int. J. of Food Sci. and Tech., 41:12221228.

Obulesu M. and Swamylingappa B. (2006). Biochemical, functional and nutritional characteristics of soy protein concentrate prepared by thermal processing. J. of Food Sci. and Tech., 43:161-166.

Oser B. L. (1951). Methods for the integrating essential amino acid content in the nutritional evaluation of protein. $J$. of American Dietetic Assoc., 27:399-404.

Oser B. L. (1959). Protein and Amino Acid Nutrition .An integrated essential amino acid index for predicting the biological value, in, ed. by Albanese A. A. Academic Press, New York, NY, pp 281-195.

Pinter S. M. and Molnar P. I. (1990). Determination of tryptophan in unhydrolyzed food and feedstuffs by the acid ninhydrin method. J. of Agri. and Food Chem., 38:720-726. 
Prasannappa G., Chandrashekhara H. N., Kailash V., Srinivas K. S., Gowri V., Murthy I. A. S. and Chandra Shekhara M. R. (1972). Pre-cooked Balahar and Indian multipurpose food. J. of Food Sci. and Tech., 9:174-178.

Rashmi K. C. and Swamylingappa B. (2009). Chemical, Functional and Nutritional characteristics of weaning food formulations. In: souvenir, 41st National conference of nutrition society of India (2009) on Chronic diseasesThe new pendemic, National Institute of Nutrition Hyderabad, 20-21 Nov, pp 90.

Rivera J. and Lutter C. (2001). The potential role of processed complementary foods in Latin America. In: Nutrition and growth, Martorell M. and Hasehke R. (Eds.) Nestle Nutrition workshop series pediatric program, Vol. 47, Lippineott Williams and Wilkins, Philadelphia, PA.

Sarwar G. and Mc Donough. F. E. (1990). Review of protein quality evaluation methods: evaluation of protein digestibility corrected amino acid score method for assessing protein quality of foods. J. of Assoc. of Offi. Anal. Chem., 73: 347-355.

Satterlee L. D. Marshall H. F. and Tennyson J. M. (1979). Measuring protein quality. J. of American Oil Chemist's Society 56:103-110.
Stone H and Sidel J. L. (1998). Quantitative descriptive analysis development, application and the future. Food Tech., 52:48-52.

Taussky H. H. and Shorr E. (1953). Micro-colorimetric method for the determination of inorganic phosphorus. $J$. of Biological Chem., 202: 675-685.

Thompson D. B. and Erdman Jr. J. W. (1982). Phytic acid determination in soybeans. J. of Food Sci., 47: 513-517.

UNICEF (2006). The state of the World's children, 2007, New York.

Wang T. and Kinsella J. E. (1976). Functional properties of novel proteins; alfalfa leaf protein. J. of Food Sci., 41:1823.

White Head R.G. (1973). Protein in Human Nutrition (Ed) Rolls A. Academic press, New York, 103.

WHO (2002). Infant and young children nutrition: Global strategy on Infant and young children feeding, World Health Assembly Document WHA 55/15, WHO press, Rome.

WHO/UNICEF (1998). Complementary feeding of young children in developing countries, a review of the current scientific knowledge, WHO Publications, Geneva. 